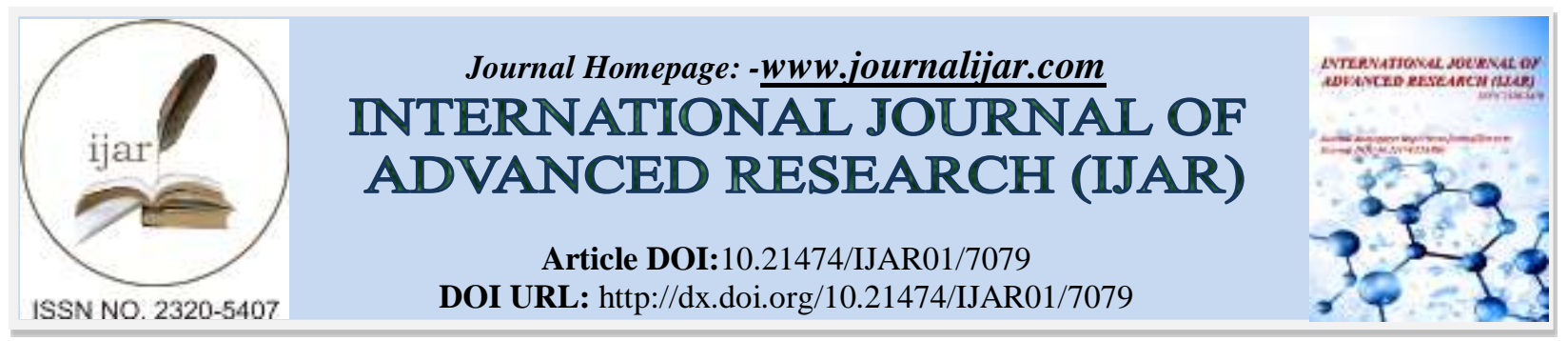

RESEARCH ARTICLE

\title{
DEVELOPMENT OF LEARNING STRATEGY BASED INQUIRY TO BUILD STUDENT ARGUMENTATION SKILLS.
}

\author{
F. Bayu Nirwana, Agus Suyatna and Chandra Ertikanto. \\ Graduate Program of Physics Education, University of Lampung, Indonesia.
}

\section{Manuscript Info}

Manuscript History

Received: 11 March 2018

Final Accepted: 13 April 2018

Published: May 2018

Keywords:-

Learning strategy, inquiry, argumentation skills.

\section{Abstract}

This study aims to develop a valid learning strategy based inquiry to build argumentation skills and to know their effectiveness in building argumentation skills. The method used is the Research and Development (R \& D) model of Dick and Carey, by identifying needs and determining goals, analyzing strategies, identifying student characteristics, formulating specific learning goals, developing benchmark reference tests, developing learning strategies, selecting learning materials, formative evaluation, and revision of learning. The object of this research is 75 students who come from 3 high schools in Bandar Lampung. The conclusions of this research are derived from argument inquiry strategy which has the components of learning objectives, learning scenarios, learning approaches, and tools and learning resources. These components are combined with right steps and methods, so the learning strategy effectively for building students argumentation skills.

Copy Right, IJAR, 2018,. All rights reserved.

\section{Introduction:-}

The global demand of 21 st-century students is that students have to master the various skills in their learning process. These skills refer to the four life principles that include learning to know, learning to do, learning to be and learning to live together. The four principles each contain specific skills that need to be empowered in learning activities, one of which is argumentation skills (BSNP, 2010).

Ways to get people to acquire skills such as processing scientific knowledge, how the scientific method used in processes, observations, classifications and conclusions, is through the making of individual thinking like a scientist (Peker, 2008). To teach people how to think like a scientist from elementary school is to familiarize people questioning problems, thinking and generating ideas (Hacioğlu, 2016). Argumentation is one approach that urges individuals to think like a scientist.

The advancement of science is usually accomplished through argument and argument. According to Ogreten (2014), argumentation skills have a positive effect on student learning outcomes. According to Jiménez (2008), the ideal learning environment characteristics for constructing arguments about students, teachers, curriculum, assessment, reflection, and communication are (1) Students must be active in the learning process. They must value knowledge, build their claims, and be critical of others. (2) Teacher must adopt for student-centered learning, (3) The curriculum should join an authentic problem approach, which will require the student to learn with the solution solving. (4) Students and teachers should be skilled in assessing claims, and assessing students should go beyond 
written tests. (5) Students should be reflective of their knowledge and understand how it is obtained, and (6) Students should have the opportunity to engage in dialogue where cooperative learning will take place. Combining these six elements encourages the implementation of an argumentative, interactive learning environment.

The argumentation skill in question is an argumentative skill expressed by Toulmin in Katchevich (2013), which consists of Claim, Warrant, Backing, Rebuttal. Figure 1 shows Toulmin's Argument Pattern.

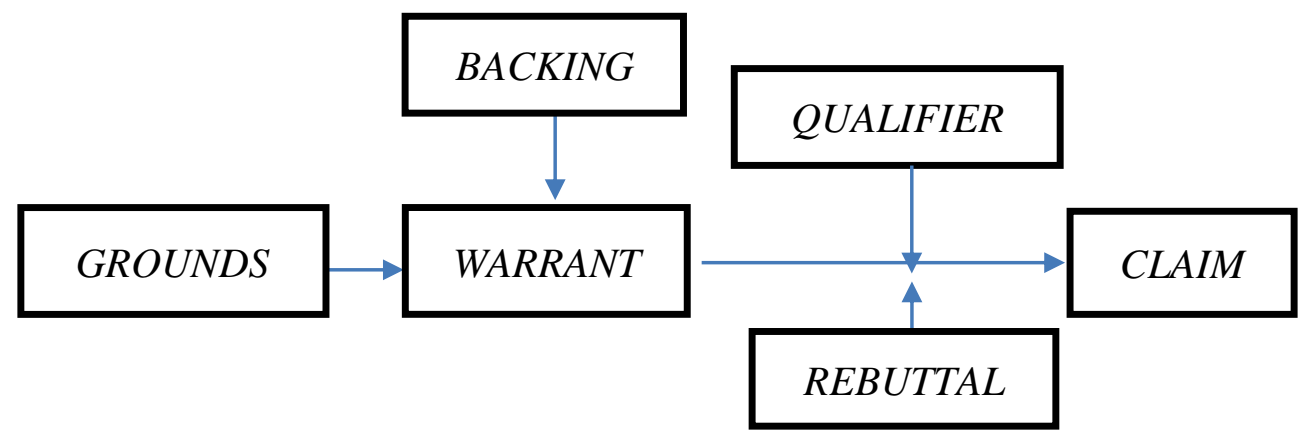

Figure 1:-Toulmin's Argument Pattern

The statements generated by each person are classified into two distinct levels of claim, warrant, support and rebuttal (Chen and She, 2012). Table 1 shows an assessment of the quality of argumentation skills using an analytical framework.

Table 1:-Analytical Framework for Determining the Quality of Arguments

\begin{tabular}{|l|l|l|}
\hline \multicolumn{1}{|c|}{ Component } & \multicolumn{1}{|c|}{ Level } & \multicolumn{1}{c|}{ Definition } \\
\hline \multirow{3}{*}{ Claim } & Level 1 & Arguments consist only of claims without data or facts \\
\cline { 2 - 3 } & Level 2 & Arguments consist of data and facts \\
\hline \multirow{3}{*}{ Backing } & Level 1 & $\begin{array}{l}\text { The argument consists only of theory or principle with no connection to the } \\
\text { claim, or it does not clearly explain the theory. }\end{array}$ \\
\cline { 2 - 4 } & Level 2 & An argument consists of a claim by theory or principle. \\
\hline \multirow{2}{*}{ Rebuttal } & Level 1 & $\begin{array}{l}\text { The argument consists only with support without a claim / warrant connection, } \\
\text { or does not clearly describe the connection between them. }\end{array}$ \\
\cline { 2 - 4 } & Level 2 & An argument consists of a claim with support, and or with data or command. \\
\cline { 2 - 4 } & Level 1 & An argument consists only of weak denial and without clear explanation. \\
\cline { 2 - 4 } & Level 2 & An argument consists of claims with clearly identified denials. \\
\hline
\end{tabular}

Source: Chen and She (2012)

The researchers used the argumentation analysis framework proposed by Chen and She (2012). In this study, researchers only measure four argumentation skills, namely claim, warrant, backing, and rebuttal. Researchers classify argument skills based on their level. Level 1 is a weak argumentation skill, while level 2 is a strong argumentation skill.

Teaching is an art form than a science (Wenning, 2011). There is no set of rules that are binding on the teacher to make a learning step. Inquiry itself is now becoming a very interesting model, as shown by the large number of international-scale articles discussing inquiry application. Teachers with a facilitating role should have skills in implementing inquiry based instruction (Ozdemir \& Isik, 2015). Several earlier studies have suggested that the application of guided inquiry in learning can improve student learning outcomes. This is also confirmed by Veloo (2013) which says that there is a positive relationship between guided inquiry with student achievement. When inquiry is applied, student achievement increases. Bekiroğlu (2013) states that guided inquiry can improve the four skills of the science process, namely the skills of identifying variables, hypothesizing, defining, and interpreting data and graphs. The guided inquiry steps according to Hanson (2012) are (1) orientation (2) exploration (3) concept forming (4) application (5) cover. Hanson's inquiry steps can develop students' learning experiences. 
Steps of guided inquiry is related to the argumentation skills, where some guided inquiry steps can build argumentation skills. This statement is supported by the statement of Katchevich (2013) which says that when students conduct experiments, especially when students conduct investigations, argumentation skills emerge. Therefore, the researcher is interested to develop the learning strategy based inquiry to build students' argumentation skills.

Learning strategy is a model of professional education through collaborative learning and continuous learning based on the principles of colleagues and mutual learning to build learning communities (Lewis, 2002). Ozawa (2009) which states that learning strategies are the activities of teachers to improve their learning process. Learning strategy is not a study of learning to make learning perfect, but lesson study makes it possible for teachers to see carefully how students learning, student engagement, and student development (Bergenske, 2008). They further explained that the intended learning strategy includes the nature, scope, and sequence of learning activities that can give learning experiences to learners.

The components of the learning strategy according to Dick and Carey (2009) are (1) preliminary learning activities (2) information delivery (3) learners participation (4) learning evaluation, and (5) follow-up activities. Components of learning strategies (David, 2010) are (1) learning goals (2) teaching and learning activities (3) methods (4) learning tools (5) learning resources, and (6) evaluation. Researchers take several components namely learning objectives, learning scenarios, learning approaches, as well as tools and learning resources.

The findings of researchers in the preliminary study, found that the learning strategies that teachers do during the learning process has not been able to build students argumentation skills. The learning process still positions the students as the recipient of information only. By devising appropriate learning strategy steps, allowing students to be actively involved during the learning process. By devising appropriate learning strategies, students' argumentation skills can be developed. Based on the description, the researcher is interested to develop of valid learning strategy based inquiry to build argumentation skills, and to know the effectiveness of learning strategy in constructing argumentation skills.

\section{Materials and Methods:-}

The research method used in this research is Research and Development (R \& D) model of Dick and Carey (2009) with steps to find needs and find goals, analyze strategies, identify student characteristics, formulate specific learning objectives, develop benchmark reference test, developing learning strategies, selecting learning materials, conducting formative evaluations, and revisions of learning. The subject of this research are 75 students from three high schools spread in Bandar Lampung City. Researchers use the test instrument, a questionable description to measure the students' arguments. Analysis of learning result data and argumentation skill using paired sample t-test analysis. The level of product effectiveness is categorized based on the average value of gain.

\section{Results and Discussions:-}

Learning strategies developed can build students' argumentation skills. Components that exist in learning strategies developed include learning objectives, learning methods, tools and learning resources, and Principles of interaction between teachers and students. Figure 2 shows the learning strategy chart developed. 


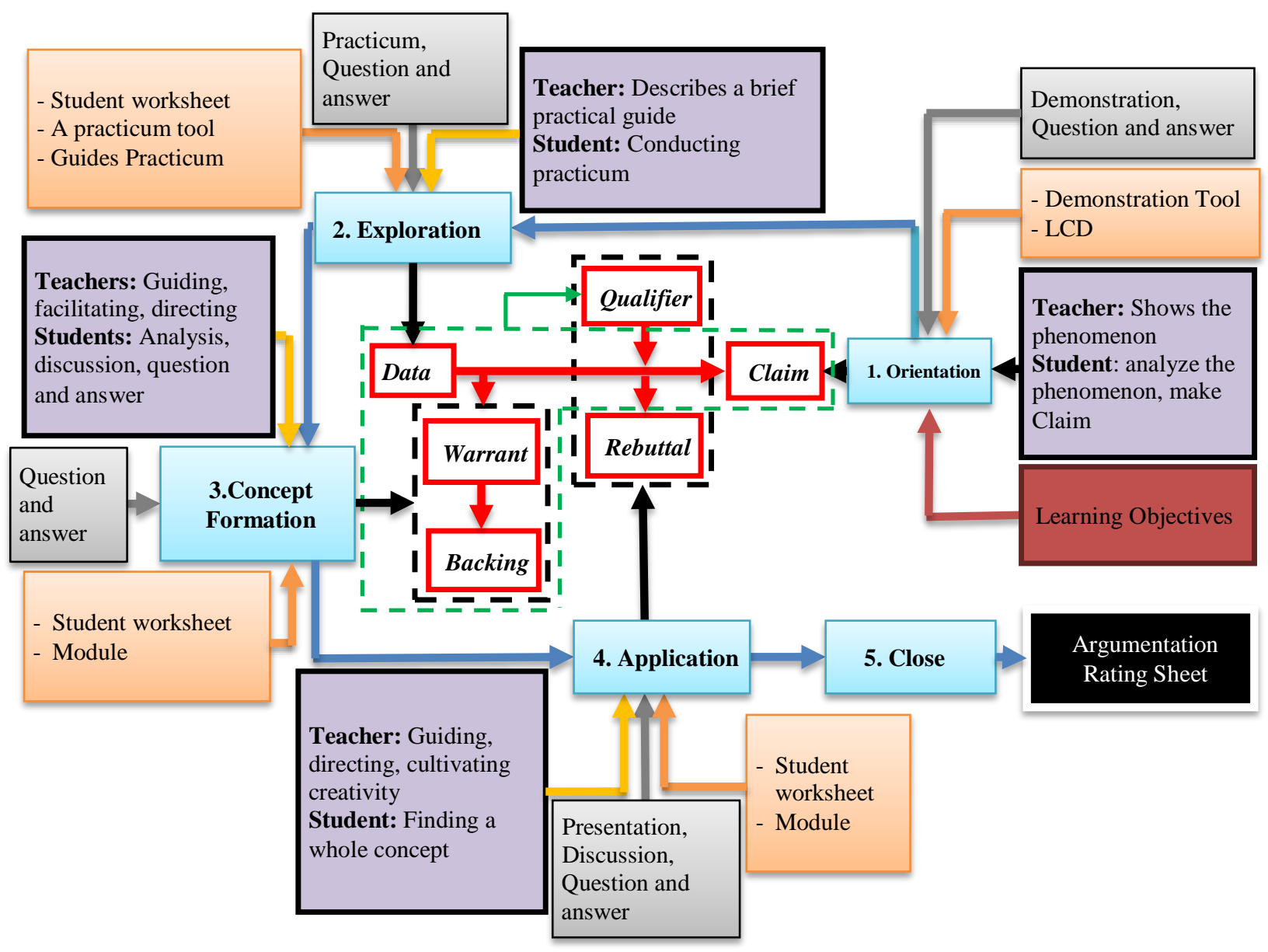

Figure 2:-Chart of Learning Strategy Based Inquiry

Substance validation test results obtained a percentage of $78.5 \%$ with high category, while yield construction validation tests get a percentage of $75.25 \%$ with high category. Table 2 shows the validation test results.

Table 2:-Expert Validation Test Results

\begin{tabular}{|l|l|c|}
\hline No & Components Assessed & $\begin{array}{c}\text { Percentage of } \\
\text { Achievement }\end{array}$ \\
\hline A. & Substance & $80 \%$ \\
\hline 1 & Conformity of strategy substance with Principle of learning strategy & $78 \%$ \\
\hline 2 & Conformity of strategy substance with component of learning strategy & $76 \%$ \\
\hline 3 & Conformity of strategy substance with inquiry phase & $80 \%$ \\
\hline 4 & Conformity of strategy substance with methods, tools, and learning resources & $76 \%$ \\
\hline 5 & Conformity of strategy substance with inquiry syntax & $76 \%$ \\
\hline B. & Construction & $76 \%$ \\
\hline 1 & Organizational fit content strategy & \\
\hline 2 & Suitability of activities from strategy to development goals & \\
\hline
\end{tabular}

A good learning strategy is a learning strategy that can make the desired learning objectives according to the indicators. In static fluid materials, most of the materials taught are concepts. Researchers use the practicum method so that students more easily master the concept. As revealed by Booney (2015) which revealed that case or practical studies are more effective than other methods of improving the performance and understanding of student concepts. The learning strategy developed already has a clear and proper sequence of learning. The sequence of the learning process is adapted to guided inquiry steps, namely orientation, exploration, concept formation, application, and 
cover. At the beginning of the lesson, students are given a case study and are given questions they must answer. At this stage, the teacher displays the video that relates to the concept being studied. The videos that are shown can foster students' motivation, interest, and curiosity (Golu, 2016). The substance of the developed learning strategy has been in accordance with the methods, tools, and learning resources used. Therefore, the learning strategy developed is considered to be valid substantially. Based on the assessment of two experts in the construction field, the developed learning strategy is possible to be used with an average value of 75.25\%. The learning strategy is considered possible from several aspects, such as the suitability of the organizational content of the learning strategy and the suitability of the learning strategy activities with the development goals.

The learning strategy chosen and used by the teacher starts from the learning objectives that have been set at the beginning. The development of learning strategies based on these inquiry steps is considered to be able to build students' argumentation skills. This is in line with the opinion of Mahardika et al (2015) which says that the application of inquiry can improve students' argumentation skills. Thus, the developed learning strategy is considered capable of achieving the learning objectives set. Thus, the learning strategy developed is considered to be valid in terms of construction.

The effectiveness of learning strategy is measured from the achievement of learning objectives and mastery learning. Figure 3 shows the recapitulation of the average increase in students' argumentation skills.

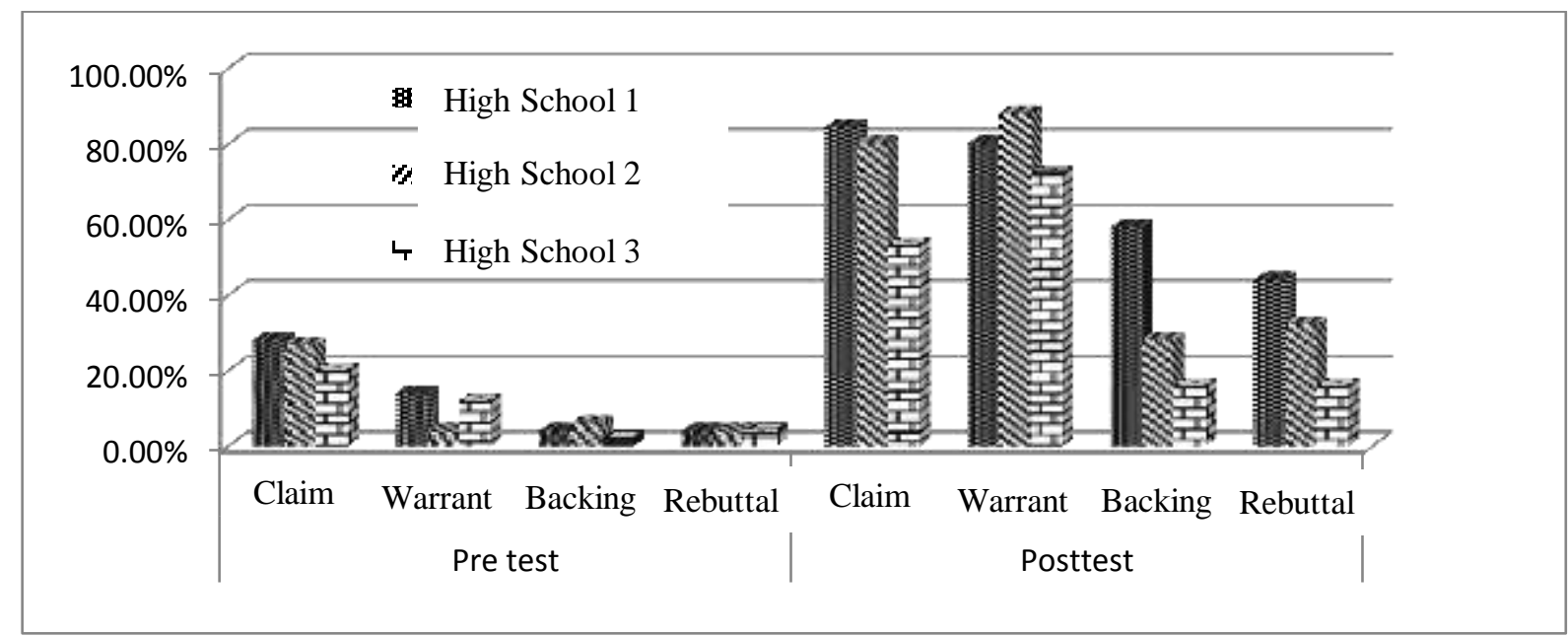

Figure 3:-Recapitulation of Percentage of Argumentation Skills

The average increase of students in making claim skills is $70 \%$ with effective category. In developed learning strategies, the skills of making claims are carried out at the beginning of the lesson. Before the students carry out the practicum, the teacher shows the video, then the students are given questions. Students answer on a baseline just watching the video that is shown by the teacher, without knowing the concept being studied. This student's reply then becomes a claim.

The average increase in the skill makes the student's warrant is $80 \%$ effective. Warrant skills are the skills of linking data with previously created claims. Warrant skills students can be mastered with the need that students must get the correct data when practicum. Practicum that students do most of them have gone through the correct steps, so the data they get is also true. Therefore, they are not too difficult when connecting data obtained with learned concepts. No wonder the skills make warrant up to $80 \%$. The steps of strategic argumentation make it easier for students to find the concepts studied, in accordance with the opinions from Gultape \& Kilic (2013) which says that learning argumentation makes it easier for students to build concepts.

The average increase in skill makes the students' backing of $30 \%$ with the category quite effective. Not much different from the skill of making backing, student's skill in making rebuttal also is at a small percentage that is $20 \%$. Backing and rebuttal skills are among the highest level of argumentation skills. To be able to master these skills, students are required to have high learning activities. For example, to make rebuttal skills, students must use all available learning resources. At the time of learning, researchers have provided the module as an extra learning 
resource. Inside the module students can find some data that can support learned concepts. In fact, students who become the subject of research is still very small to seek information in the module provided. Thus, the students' backing and rebuttal argument skills are low. This is in accordance with Farida \& Gusniarti's (2014) statement that students have difficulty in making arguments, because students are poorly trained to use relevant literature sources, and are not yet accustomed to making an argument. This also affects the lack of experience of students in carrying out learning activities that involve students' argumentation skills. This is by the statement of Viyanti, et al. (2017) that to express a simple argument consisting of only one statement of course the learner has difficulty, it indicates that the learner is less experienced in cultivating argumentation skills on his or her learning.

The effectiveness of learning strategies is also measured using student learning mastery indicators. Learning completeness seen from student learning outcomes. Similar to argumentation skills, students' learning outcomes are obtained through pretest and posttest, and then seen as increments or N-Gains. Table 3 shows the average student learning outcomes.

Table 3:-Average Score of Student Learning Results

\begin{tabular}{|c|l|l|l|l|}
\hline \multirow{2}{*}{ High Schools } & \multicolumn{2}{|c|}{ Nean } & \multirow{2}{*}{ Category } \\
\cline { 2 - 5 } & Pretest & Posttest & \\
\hline 1 & 29.6 & 80.9 & 0.7 & High \\
\hline 2 & 25.7 & 75.3 & 0.7 & High \\
\hline 3 & 21.0 & 54.3 & 0.4 & Medium \\
\hline
\end{tabular}

Based on table 3, we can see that the average learning outcomes of all three schools have increased after the researchers applied the inquiry strategy to argue. The value of the greatest learning results obtained students of High School 1 and the lowest value obtained students of High School 3. For the average N-Gain, students of High School 1 and High School 2 get the same score, that is 0.7 with effective category. High School 3 obtained the lowest NGain, which is 0.4 with quite effective category.

The process undertaken during the learning takes place greatly affects student learning outcomes. Step by step in learning activities are usually more familiar with the term learning scenario. In the developed learning strategy, learning scenarios are arranged for students to be active during the learning process.

Physics is a learning in which there are many concepts that are still abstract. Providing direct experience to students is one way that can be taken to overcome this problem. In the developed learning strategy, researchers give direct experience to students through practicum. This is in line with the statement Sutarno (2013) which states that the application of practicum based problem solving makes it easy to understand the concept of abstract physics. Learning scenarios are also designed to enable students to be active during the learning process. The way that researchers do to make students active during the learning process is a practicum executed designed using guided inquiry approach. The steps that exist in guided inquiry lead many students to be active during the learning process. At the time of the study, one of the steps that requires active students is when students are asked to investigate the relationship between depth and pressure. In one group the students each have different tasks. There are students who duty to dip the tool into the water, there is a duty to see the depth of the object, there is a duty to read altitude, and there are also students in charge of recording the results of the experiment.

The division of tasks assigned to each individual student makes all the students in the group actively involved during the learning process. By actively engaging in the process of practicum, students become aware of the concepts being studied. Thus, student learning outcomes also become good. This is in line with the opinion of Laird et al (2008) which reveals that students who have high discipline and activity get high learning results.

\section{Conclusions And Recommendations:-}

The strategy of arguing inquiry is the name of the developed learning strategy. Inquiry strategy to argue have several components, including learning objectives, learning scenarios, learning approaches, and learning tools and resources. Inquiry strategy to arguing for effective development results to build students' argumentation skills. This is based on a significant increase in argumentation skills with a sig $<0,05$ value. Inquiry strategies argue effectively for improving students' skills of making claims and warrants, effective enough to improve the skills of backing, but are less effective in improving rebuttal skills. 
Based on the result of this research, the researcher gives suggestion that inquire strategy to argue the result of development can be used to build student's argumentation skills on other physics material, but the learning scenario must be adjusted with the material being studied. The researcher also suggests the development of further learning strategies to maximize the argumentation skills, especially rebuttal.

\section{References:-}

1. Badan Standar Nasional Pendidikan. (2010). Paradigma Pendidikan Nasional Abad-XXI. Jakarta: BSNP.

2. Bekiroğlu, F. O. (2013). Examination of the Effects of Model-Based Inquiry on Students' Outcomes: Scientific Process Skills and Conceptual Knowledge. Procedia - Social and Behavioral Sciences. 141 (14): 1187-1191.

3. Bergenske, L. D. (2008). Lesson Study: Implication of Collaboration Between Education Specialists and General Education Teacher. Science Education. 88 (1): 111-135.

4. Booney, K., M. (2015). Case Study Teaching Method Improves Student Performance and Perceptions of Learning Gains. Journal of Microbiology and Biology Education. 16 (1): 21-28.

5. Chen, C. T., \& She, H. C. (2012). The Effectiveness of Scientific. Inquiry With/Without Integration of Scientific Reasoning. International Journal of Science and Mathematics Education. 2 (1):98-118.

6. David, W. J. (2010). Colaborative Learning: Strategi Pembelajaran Untuk Sukses Bersama. Jakarta: Nusamedia.

7. Dick, W. \& Carey, J. O. (2009). The Systematic Design of Instruction. USA: Pearson Education.

8. Farida, I., \& Gusniarti. (2014). Profil Keterampilan Argumentasi Siswa Pada Konsep Koloid Yang Dikembangkan Melalui Pembelajaran Inkuiri Argumentatif. Edusains. 6 (1): 31-40

9. Golu, S. F. (2016). Penggunaan Media Video untuk Meningkatkan Minat Belajar Ipa Kelas IV SD Negeri Bakalan. Jurnal Pendidikan Guru Sekolah Dasar. 7 (5): 692-702.

10. Gultape, N. \& Kilic, Z. (2013). Scientific Argumentation and Conceptual Understanding of High School Students on Solubility Equilibrium and Acids and Bases. Turkish Science Education. 10 (4): 5-21

11. Hacığlu, Y. (2016). Pre-Service Science Teachers' Cognitive Structures Regarding Science, Technology, Engineering, Mathematics (STEM) and Science Education. Turkish Science Education. 13 (2): 88-102.

12. Hanson, D. M. (2012). Designing Process Oriented Guided Inquiry Activities. Stony Brook University SUNY: Pacific Crest.

13. Jiménez, A. (2008). Argumentation in science education: Perspectives from classroom-based research. Turkish Science Education. 43 (1): 317-345.

14. Katchevich, D. (2013). Argumentation in the Chemistry Laboratory: Inquiry and Confirmatory Experiments. Res Science Education. 43 (2): 317-345.

15. Laird, T. F. N., Shoup, R., Kuh, G. D., \& Schwarz, M. J. (2008). The Effects of Discipline on Deep Approaches to Student Learning and College Outcomes. Res High Educ. 49 (6): 469-494.

16. Lewis, C. C. (2002). Lesson study: A Handbook of Teacher-Led Instructional Change. Phila-delphia: Research for Better Schools.

17. Mahardika, A. I., Fitriah, \& Zainuddin. (2015). Keterampilan Argumentasi Ilmiah Pada Pembelajaran Fisika Melalui Model Pembelajaran Inkuiri Terbim-bing. Jurnal FKIP Unlam. 27 (7): 755-762.

18. Ogreten, B. (2014). Examining the Effectiveness of Science Teaching Based on Argumen-tation. Turkish Science Education. 11 (1): 75-100.

19. Ozawa, H. (2009). Lesson Study in Mpumalanga Province, South Africa. CICEseries. 5 (3): 175-193.

20. Ozdemir, O. \& Isik, H. (2015)._Effect of Inquiry-Based Science Activities on Prospective Elementary Teachers' Use of Science Process Skills and Inquiry Strategies. Turkish Science Education. 12 (1): 43-56.

21. Peker, D. (2008). Scientific Explanations And Arguments, New Approaches in Teaching Science and Technology. Pegem Akademi Publishing: 9 (1): 265-311.

22. Sutarno. (2013). Pengaruh penerapan praktikum virtual berbasis problem solving terhadap kemampuan berpikir kritis mahasiswa. Prosiding Semirata FMIPA Universitas Lampung (pp. 81-89). Lampung: FMIPA Universitas Lampung.

23. Veloo, A. (2013). Inquiry-based instruction, students' attitudes and teachers' support towards science achievement in rural primary schools. Procedia - Social and Behavioral Sciences. 93 (1): 65-69.

24. Viyanti, Cari, Sunarno, W., Prasetyo, Z., \& Widoretno, S. (2017). The development rubrics skill argued as alternative assessment floating and sinking materials. Journal of Physics: Conf. Series. 909: 1-7.

25. Wenning, C. J. (2011). The Levels of Inquiry Model of Science Teaching. Journal of Physics Teacher Education Online. 6 (6): 9-16. 